\title{
Mechanics and Mathematicians: George Biddell Airy and the social tensions in constructing time at Parliament, 1845-1860
}

In mid-Victorian Britain, reconciling elite mathematical expertise with practical mechanical experience presented both engineering and social challenges. This was especially apparent in the construction of accurate time-keepers. Transforming theoretical drawings on paper into working clocks of brass and iron involved the knowledge of both university-trained wranglers and workshop-conditioned artisans, but this entailed not just mechanical organization, but social management. Nowhere was this interaction more troublesome than in the building of the world's most famous nineteenth-century timekeeper, the Westminster Clock housed in St Stephen's Tower at the Houses of Parliament (popularly, if incorrectly known as 'Big Ben'). This machine was intended to project time of unparalleled accuracy, recorded at the Royal Observatory at Greenwich, for the nation's governing legislature, and society more broadly. Realizing this scheme engendered the collaboration between the Astronomer Royal George Biddell Airy (1801-1892) and Edmund Beckett Denison (1816-1905), both veterans of Cambridge's rigorous Mathematical Tripos Examinations, and the skilled clock-maker Edward John Dent (1790-1853). Between these three individuals, each with differing claims of expertise, understandings of accuracy, and class credentials, negotiations over mechanical arrangements challenged Victorian social hierarchies.

This article is about knowledge and social order. It argues that class shaped the design and construction of the Westminster Clock but, at the same time, that models and mechanisms constituted a material culture for managing social relations. This was a moment when mechanical objects provided material solutions to social disorder and ambiguities over authority. The task of building this machine entailed a collaboration of elite mathematicians and skilled mechanics which disrupted traditional distinctions between 'gentleman of science' and artisan. ${ }^{1}$ Transforming theoretical mathematical drawings into physical apparatus challenged existing relations between conveyors of privileged scientific knowledge, and those with practical experience of what was, and what was not, mechanically possible. But the project also involved strained relations between mathematicians with contrasting class credentials. Through my analysis, this paper offers insights into the role of class consciousness in Victorian mathematical practice and the very real social anxieties that arose when mathematicians of different social positions tried to work together.

In Victorian horology there were four principal technical challenges to building a clock. The first was to provide a driving source of power, either using a spring or falling weight. Second, a regulator of this power was required, usually in the form of an escapement. The third problem was the going-train, which was a device for keeping count of the clock's movement and, finally, a clockmaker had to construct a means of displaying the time kept. To ensure accuracy for the Westminster Clock, it was essential to design an escapement device which could convert the driving power of its falling weight into the

1 Term taken from, Jack Morrell and Arnold Thackray, Gentlemen of Science: early years of the British Association for the Advancement of Science, (Oxford, 1981); for a classic study of class see E. P. Thompson, The Making of the English Working Class, (Penguin: London, 1991); on class in the 1830s and 1840s, see Boyd Hilton, A Mad, Bad, \& Dangerous People? England 1783-1846, (Clarendon Press: Oxford, 2006), pp. 622-5. 
regular beats of its swinging pendulum. This was a point of divergence between mathematical theory and mechanical practice, with the problem of circular error, that is the deviation between an ideal pendulum oscillation and its actual arc of movement, a hard one to be reconciled between mathematical formulae and the workings of a clock. ${ }^{2}$

With Dent the builder, Denison the designer, and Airy the supervisor, the three men responsible for constructing Parliament's new clock were socially varied: class differences shaped relations between these collaborators. Born in Alnwick, Airy's parents were from farming stock, with his mother, Ann Airy, the daughter of a 'well-to-do' Suffolk farmer and his father, William Airy, originally a foreman on a farm in Luddington before becoming an Excise officer, rising to the rank of Collector until losing his job in $1813 .^{3}$ Airy was educated at Colchester Royal Grammar School after attending elementary schools in Hereford. He entered Trinity College Cambridge in 1819 and rapidly became the mathematical star of the early 1820s under the coaching of George Peacock (1791-1858), being Senior Wrangler in the Mathematical Tripos of 1823 and then authoring Mathematical Tracts in 1826 which effectively became the University's mathematical textbook. ${ }^{4}$ He was central to the post- 1815 English mathematical revival which saw the adoption of French-style analysis. ${ }^{5}$ He was in many ways the ideal of Jack Morrell and Arnold Thackray's conception of a 'gentleman of science'. ${ }^{6}$ Having become Cambridge's Lucasian Professor of Mathematics in 1826, and then Plumian Professor of Astronomy with responsibility for the University's observatory in 1828 , he succeeded John Pond as Astronomer Royal in 1835.

Edmund Beckett Denison had also endured Cambridge's mathematical training at Trinity College, passing as Thirtieth Wrangler in the 1838 Tripos Examinations. But unlike Airy, who was of a middle class upbringing and of limited financial means, Denison was from a far more privileged position of wealth and social rank. Having attended Eton, he was well connected, being the son of an MP for Doncaster and marrying the daughter of the

2 Charles McKay, Big Ben: the great clock and the bells at the Palace of Westminster, (Oxford, 2010), p. 55.

3 Wilfrid Airy (ed.), Autobiography of Sir George Biddell Airy, (Cambridge, 1896), pp. 14-5 and 17.

4 Allan Chapman, 'Airy, Sir George Biddell (1801-1892)', Oxford Dictionary of National Biography, Oxford University Press, 2004; online edn, Jan 2011 [http://ezproxy.ouls.ox.ac.uk:2117/view/article/251, accessed 20 Aug 2017]; Allan Chapman, 'George Biddell Airy, F. R. S. (1801-1892): a centenary commemoration', Notes and Records of the Royal Society of London, Vol. 46, No. 1 (Jan., 1992), pp. 103-10; George Biddell Airy, Mathematical Tracts on Physical Astronomy, the figure of the earth, precession and nutation, and the calculus of variations, (Cambridge, 1826); on Cambridge mathematics, see Andrew Warwick, Masters of Theory: Cambridge and the rise of mathematical physics, (Chicago, 2003).

5 I. Grattan-Guinness, 'Mathematics and mathematical physics from Cambridge, 1815-40: a survey of the achievements and of the French influences', in P. M. Harman (ed.), Wranglers and Physicists: studies on Cambridge mathematical physics in the nineteenth century, (Manchester, 1985), pp. 84-111; also see, Raymond Flood, Adrian Rice, and Robin Wilson (eds.), Mathematics in Victorian Britain, (Oxford, 2011).

6 On defining 'gentlemen of science, see Jack Morrell and Arnold Thackray, Gentlemen of Science: early years of the British Association for the Advancement of Science, (Oxford, 1981), pp. 21-9; for Airy within this, see pp. $23-7$. 
Bishop of Lichfield. An evangelical Anglican, Denison began a career as a lawyer in 1841, and subsequently pursued horology as a gentleman amateur. He published A Rudimentary Treatise on Clock and Watch Making in 1850, as well as articles on clocks, watches, and bells, for the Encyclopedia Britannica, and chaired the horological jury at the 1851 Great Exhibition. $^{7}$

In many ways, while Airy ever remained the grammar school boy, never quite at ease with his financial position throughout his career and sensible of his social background, Denison had no such anxieties. In 1830, Airy married Richarda Smith (1804-1875), but had had to wait six years to attain a financial position in which he was able to do so. Similarly, although he was knighted in 1872, he had previously refused the title, first in 1835 claiming that his material income was 'hardly sufficient ... to support respectably the honor', and then again in 1863 on the same grounds. ${ }^{8}$ Despite their mathematical training, Airy and Denison had upbringings of differing degrees of privilege. That Airy had to earn an income, and that Denison was a gentleman of means, set the two Cambridge wranglers apart.

In contrast, Dent had no university education, but had worked his way up as a highly respected manufacturer of chronometers. Owning shops in Westminster at 33 Cockspur Street and 82 the Strand, and a factory near the Strand at Somerset Wharf, Dent had progressed from the rank of an artisan to what Jenny Bulstrode has termed an 'independent industrialist'. $\quad$ In 1829 his Chronometer No. 114 won the Royal Observatory's premium award, while his experiments on mercury-filled pendulums to compensate for temperature fluctuations attracted interest at the 1838 British Association for the Advancement of Science meeting. ${ }^{10}$

Though there was clearly a lot of mutual respect between the mechanic and the two university-educated mathematicians, there was also much social tension. While Dent might reflect that the 'mechanical world in my opinion lost its greatest genius when Mr Airy became an Astronomer', both Airy and Denison were eager to maintain the social order between gentlemen mathematician and mechanic. ${ }^{11}$ This question of authority and social rank was one that Airy never forgot. On one occasion to the Admiralty, he alleged that 'a man of

7 Peter Ferriday, Lord Grimthorpe, 1816-1905, (London, 1957), pp. 7 and 20; L. C. Sanders, 'Beckett, Edmund, first Baron Grimthorpe (1816-1905)', rev. Catherine Pease-Watkin, Oxford Dictionary of National Biography, Oxford University Press, 2004; online edn, May 2007 [http://ezproxy.ouls.ox.ac.uk:2117/view/article/30665, accessed 27 Aug 2017]; Edmund Beckett Denison, A Rudimentary Treatise on Clocks and Watches, and the Bells; with a full account of the Westminster Clock and Bells, (London, 1860); Edmund Beckett Denison, Clocks and Locks. From the "Encyclopaedia Britannica." Second edition; with a full account of the great clock at Westminster, (Edinburgh, 1857).

8 Airy (ed.), Autobiography of Sir George Biddell Airy, pp. 112-3 and 254-6.

9 Jenny Bulstrode, 'Riotous assemblage and the materials of regulation', History of Science, Vol. 56, No. 3 (Sep., 2018), pp. 278-313, 297.

10 G. C. Boase, 'Dent, Edward John (1790-1853)', rev. Anita McConnell, Oxford Dictionary of National Biography, Oxford University Press, 2004; online edn, May 2007 [http://ezproxy.ouls.ox.ac.uk:2117/view/article/7512, accessed 20 Aug 2017]; Vaudrey Mercer, The Life and Letters of Edward John Dent: chronometer maker and some accounts of his successors, (The Antiquarian Horological Society: London, 1977). 
respectable rank in society' could avoid the risks of 'being corrupted by makers of chronometers' or of 'losing authority over subordinate assistants'. ${ }^{12}$ At the Royal Observatory he instilled a rigid 'factory mentality' in which the division of labour was hierarchical; Airy's assistants were paid little and carefully managed, usually with the aid of self-regulating instruments to reduce any error in astronomical observations from 'personal equation'. ${ }^{13}$ For Airy, astronomical work was about social order and management along workshop lines, and he generally held that assistants and workmen were not to be trusted, but disciplined.

However, disciplining his collaborators in the building of the Westminster Clock was more difficult than ordering astronomer assistants at Greenwich, largely because the project's scale drew on a range of different skills. Contrary to Charles McKay's claim that Denison 'single-handedly' designed the machine, which 'could only be the result of logic and scientific thought', transferring mathematical theory into a working clock involved compromise and discussion. ${ }^{14}$ In his study of Airy and horology, Jim Bennett explained how 'Theoretical considerations, handled mathematically, had led him into escapement design and in turn into practical questions of constructing clocks', but this was far from a simple process. ${ }^{15}$ It is true that in early Victorian Britain, mathematics was usually connected to mechanical problems, often concerning machinery, and Airy was exemplary of this tradition. For example, he applied mathematics practically to calculate the positioning of magnets and compasses to solve the problem of magnetic deviation caused by iron ships. ${ }^{16}$ Similarly, he delivered papers at the Cambridge Philosophical Society in 1825 and 1826, the first 'On the forms of teeth of wheels' and the second on theoretical horology, providing mathematical investigations of horological problems. In the first, he analyzed the action of two meshing

11 J. A. Bennett, J. A., 'George Biddell Airy and Horology', Annals of Science, Vol. 37, Issue 3 (1980), pp. 269$85,280$.

12 Airy quoted in, Simon Schaffer, 'Astronomers Mark Time: discipline and the personal equation', Science in Context, Vol. 2, Issue 1 (Mar., 1988), pp. 115-45, 121.

13 Simon Schaffer, 'Astronomers Mark Time: discipline and the personal equation', Science in Context, Vol. 2, Issue 1 (Mar., 1988), pp. 115-45, 121-2; Allan Chapman, 'Sir George Airy (1801-1892) and the concept of international standards in science, timekeeping and navigation', Vistas in Astronomy, 28 (1985), pp. 321-8.

14 Charles McKay, Big Ben: the great clock and the bells at the Palace of Westminster, (Oxford, 2010), pp. 75 and 147.

15 J. A. Bennett, J. A., 'George Biddell Airy and Horology', Annals of Science, Vol. 37, Issue 3 (1980), pp. 269$85,273$.

16 See Alison Winter, “Compasses All Awry": the iron ship and the ambiguities of cultural authority in Victorian Britain', Victorian Studies, Vol. 38, No. 1 (Autumn, 1994), pp. 69-98; on English mathematics, see A. D. D. Craik, "Victorian "applied mathematics", in Raymond Flood, Adrian Rice, and Robin Wilson (eds.), Mathematics in Victorian Britain, (Oxford, 2011), pp. 177-98, 178; for an overview, see Raymond Flood, Adrian Rice, and Robin Wilson (eds.), Mathematics in Victorian Britain, (Oxford, 2011); onl mechanical applications, see Joan L. Richards, 'Mathematics in Victorian Britain by Raymond Flood; Adrian Rice; Robin Wilson. Review', Isis, Vol. 104, No. 4 (Dec., 2013), pp. 853-5, 854. 
toothed wheels and in the second an examination of small disturbances to the oscillation of a pendulum and the actions of various escapements. In both cases, theoretical mathematics was employed to resolve practical, mechanical challenges. ${ }^{17}$ Nevertheless, transferring this theory into practice was a complex process in which Airy's mathematical expertise did not in itself secure him complete authority to discipline his collaborators.

At the same time, this article demonstrates how building the Westminster Clock also involved strained relations between Airy and Denison. Though both Cambridge wranglers, they had contrasting approaches to dealing with skilled artisans. Airy appears to have had a strong distrust of craftsmen and was eager to discipline their labour with much more vigor than Denison, who became increasingly confident in Dent's practical experience. He even mobilized this skill in challenging Airy's authority as project supervisor. These contrasting exchanges with artisanal craft reflected Airy and Denison's class credentials. Denison, a solid member of the aristocracy, evidently had few concerns over relying on Dent's judgement, unlike Airy, who was much more conscious of the thin social boundaries between Dent and himself. So at the same time that this article explores mid-Victorian gentlemanartisan collaboration, it also offers insights on how social position and class shaped relations between gentlemen mathematicians.

In analyzing the construction of the Westminster Clock, my paper contributes to an extensive historical literature on science, artisans, and class. Ian Inkster's study of provincial mechanics' institutes between the 1820s and 1850s as places of social aspiration emphasized how, in the context of socio-economic fluctuation resulting from Britain's rapid industrialization, artisanal skill was central to a period of confusion over class hierarchy. ${ }^{18}$ More recently, Steven Shapin's concept of the 'Invisible Technician has drawn historians' attention to the role of unseen skilled labour behind the production of scientific knowledge, much of which was unaccredited. This acknowledgment of the epistemological value of handwork, as much as headwork, in the division of scientific investigation has been particularly productive for studies of nineteenth-century social relations. ${ }^{19}$ While in the eighteenth century, skilled instrument makers had been able to secure acclaim and membership of elite institutes, such as the Royal Society, Iwan Morus has observed that during the $1820 \mathrm{~s}$ and $1830 \mathrm{~s}$, there was increasing hostility between natural philosophers and instrument makers. In his 1830 Preliminary Discourse on the Study of Natural Philosophy, for instance, John Herschel was eager to draw distinctions between science and craft, while Simon Schaffer has explored the arguments between Charles Babbage and Joseph Clement over the Difference Engine during the 1820s to show how such disputes over the ownership of knowledge could result from collaborations between designers and makers. ${ }^{20}$

17 J. A. Bennett, J. A., 'George Biddell Airy and Horology', Annals of Science, Vol. 37, Issue 3 (1980), pp. 269$85,270-1$

18 Ian Inkster, 'Science and the Mechanics' Institutes, 1820-1850: the case of Sheffield', Annals of Science, 32:5, (1975), pp. 451-474.

19 Steven Shapin, 'The Invisible Technician', American Scientist, Vol. 77, No. 6 (Nov.,-Dec., 1989), pp. 55463. 
Likewise, Anne Secord's analysis of artisan botanists in early-Victorian Britain has shown the active role of working class and lower middle class networks were central to the production of natural history. Examining the correspondence over botanical collections between artisan and gentlemen botanists, she showed how letters were places of class tension, where issues of social hierarchy could be resolved. ${ }^{21}$ My analysis of the Westminster Clock's construction argues that, beyond correspondence, models and physical apparatus also embodied these social tensions. And just as correspondence provided sites of managing questions of class hierarchy, there was a material culture to such social negotiations. Model's played a vital role in bridging the worlds of theory and practical mechanical construction, as well as class hierarchies. Through tactful discussions, mundane practices, and material artefacts, questions of mechanical and social order could be resolved.

\section{Science and Skill}

Writing to Airy in June 1846, Charles Canning, First Commissioner of Woods and Forests with responsibility for Britain's public architecture, explained that Parliament's new turret clock should be 'the very best which British science and skill' could produce. ${ }^{22}$ To ensure this, the government had empowered Canning to invite the Astronomer Royal to oversee the appointment of a clockmaker and provide him with horological guidelines. In response, Airy rejected suggestions that such a project could be entrusted to 'one Experienced mechanic', and proposed that he himself should oversee the clock's construction. In addition to recommending that clockmakers Benjamin Vullaimy, John Whitehurst, and Dent each submit designs and compete for a contract, he provided a series of technical specifications to ensure an accuracy equal to an astronomical clock, including that the clock's striking mechanism be accurate to less than a second..$^{23}$ Above all, he was adamant that the acceptance of submitted plans and approval of the eventual completed clock both be entrusted to the Astronomer Royal, which was of course himself.

20 Iwan Rhys Morus, 'Invisible technicians, instrument-makers and artisans', in Bernard Lightman (ed.), A companion to the history of science, (John Wiley: Chichester, 2016), pp. 138-152, 138-9 and 141; Simon Schaffer, 'Babbage's intelligence: calculating engines and the factory system', Critical Inquiry, 21:1, (Autumn, 1994), pp. 203-227, 216-7.

21 Anne Secord, 'Corresponding interests: artisans and gentlemen in nineteenth-century natural history', British Journal for the History of Science, 27, (1994), pp. 383-408; Anne Secord, 'Science in the pub: artisan botanists in early nineteenth-century Lancashire’, History of Science, 32:1, (1994), pp. 269-315.

22 Royal Greenwich Observatory Archives, Cambridge University Library, (RGO)/6/607, 'Correspondence on New Palace Clock, 1845-1848', Charles Canning to Airy (20 Jun., 1846), pp. 6-8, 6; on Airy's government work see, Adam Perkins, "Extraneous Government Business": the Astronomer Royal as government scientist: George Airy and his work on the commissions of state and other bodies, 1838-1880', Journal of Astronomical History and Heritage, Vol. 4, No. 2 (2001), pp. 143-54; Stephen Courtney, 'The Historical Meridian: Antiquity and Scripture in the public work of George Biddell Airy', Journal for the History of Astronomy, Vol. 49, No. 2 (2018), pp. 135-57.

23 RGO)/6/607, Charles Canning to Airy (20 Jun., 1846), p. 7; RGO/6/607, Airy to Charles Canning (22 Jun., 1846), pp. 9-16, 10-1. 
Canning gratefully agreed to all of Airy's demands and the three clock builders were invited to compete. Annoyed at being asked to compete, architect Charles Barry having previously promised him the contract privately, Vulliamy refused to tender designs, but both Whitehurst and Dent submitted drawings in the Spring of $1847 .{ }^{24}$ Airy had previously visited Whitehurst's factory in Derby to examine clocks under construction and his tools and workshop facilities, as well as Dent's establishments in London. Dent had a workshop at 82 the Strand and a factory near the Thames at Somerset Wharf, and while he had a lathe $3 \mathrm{ft}$ in diameter and excellent smaller lathes, his teeth-cutting apparatus was not competent for very large wheels. From these inquiries, Airy concluded that Dent's workshop was larger and equipped with superior tools than Whitehurst's, including larger lathes. Despite this, he thought both would require 'considerable assistance' from an 'Engineer's establishment' to construct the clock's large wheel. ${ }^{25}$ Along with tools and factory space, Dent's price of $£ 1,600$ compared well to Whitehurst's $£ 3,373$.

It is clear, however, that Dent was always Airy's favoured competitor. Dent had in fact declared privately to Airy that he would apply to build the clock in the summer of 1845 , and the two had already collaborated in the construction of the Royal Exchange Clock, which Airy believed to be the 'best in the world as regards accuracy of going'. ${ }^{26}$ It was the mechanical accuracy that Dent provided which so impressed Airy, along with the knowledge that Dent would follow his instructions. Airy therefore advised the government to accept Dent's tender, observing that until recently Dent had specialized in chronometers, which equipped him with skills for producing extreme accuracy. At the Observatory, the business of checking marine chronometers had occupied much of Airy's time during the 1830s and 1840 s, with the annual premium trials established in 1823 to help ensure accurate timekeepers for the Royal Navy. ${ }^{27}$ This experience of chronometer construction was something Airy appreciated, with the checking of such intricate timekeepers for the Royal Navy a central part of his early work at Greenwich. He surmised that while Dent could soon acquire Whitehurst's experience, Whitehurst could not easily acquire Dent's 'accuracy'. ${ }^{28}$ While Whitehurst was a fine 'mechanic', Dent promised 'science, stability of fixing, and engineering' to guarantee accuracy. ${ }^{29}$

24 On debates with Vulliamy, see Edward J. Gillin, The Victorian Palace of Science: scientific knowledge and the building of the Houses of Parliament, (Cambridge University Press: Cambridge, 2017), pp. 234-8.

25 RGO/6/607, Airy to Viscount Morpeth (27 Mar., 1847), pp. 51-2; RGO/6/607, G. B. Airy, 'Memoranda of conversation with M. Dent on Saturday 1847 Jan. 23' (23 Jan., 1847), pp. 146-7, 147.

26 RGO/6/607, E. J. Dent to Airy (20 Jul., 1845), p. 132; RGO/6/607, Airy to E. J. Dent (22 Jul., 1845), p. 134.

27 J. A. Bennett, J. A., 'George Biddell Airy and Horology', Annals of Science, Vol. 37, Issue 3 (1980), pp. 26985, 269-70 and 273-7; on Airy and Greenwich, see Jessica Ratcliff, The Transit of Venus Enterprise in Victorian Britain, (London: Pickering \& Chatto, 2008), pp. 29-31.

28 RGO/6/607, Airy to Alexander Milne (18 May, 1847), pp. 58-63, 61.

29 Gillin, The Victorian Palace of Science, p. 226; on Dent and Airy's collaboration see, Mercer, The Life and Letters of Edward John Dent, pp. 42-4 and 128-48. 
Once Airy had assumed a position effectively as supervisor to the Westminster Clock's construction, he received several unsolicited offers to build it or provide advice on its design, and though he ignored most of these, in December 1846 a letter from Edmund Beckett Denison succeeded in catching his eye. Denison claimed to have designed a clock escapement which fit Airy's specifications 'that the impulse should be given through equal small arcs on each side of $0^{\circ} \ldots$ and that the impulse should be independent of the train of the clock'. To do this, Denison used a gravity escapement, but having read Airy's Cambridge Philosophical Transactions paper on escapements, he recognized that the problem with such mechanisms was that the pendulum constantly acted on it. After seeing a clock motion going in Dent's shop window, in which arms on axles were moved up and down by a moving pendulum, and seeing how this avoided any force but friction acting on the action, Denison had met up with Dent and discussed the practicality of his own designs. ${ }^{30}$

Airy was impressed. As the son of an MP and baronet, Denison had immaculate social credentials to combine with his wrangler status, which certainly caught Airy's attention. But the Astronomer Royal also acknowledged that Denison had a talent for clock design and sent him a model of Dent's Royal Exchange Clock remontoire action escapement. He explained that the ultimate goal for horologists was to design and build an escapement which required no oil, having no continuous unnecessary friction. ${ }^{31}$ Denison redesigned his escapement in reference to Airy's comments, believing the new design satisfied 'the three conditions, of giving the impulse at the right time, being a remontoir, and acting on the pendulum without friction - having only rolling and not sliding friction'. ${ }^{32}$ He replaced the pins attached to the arms with small wheels.

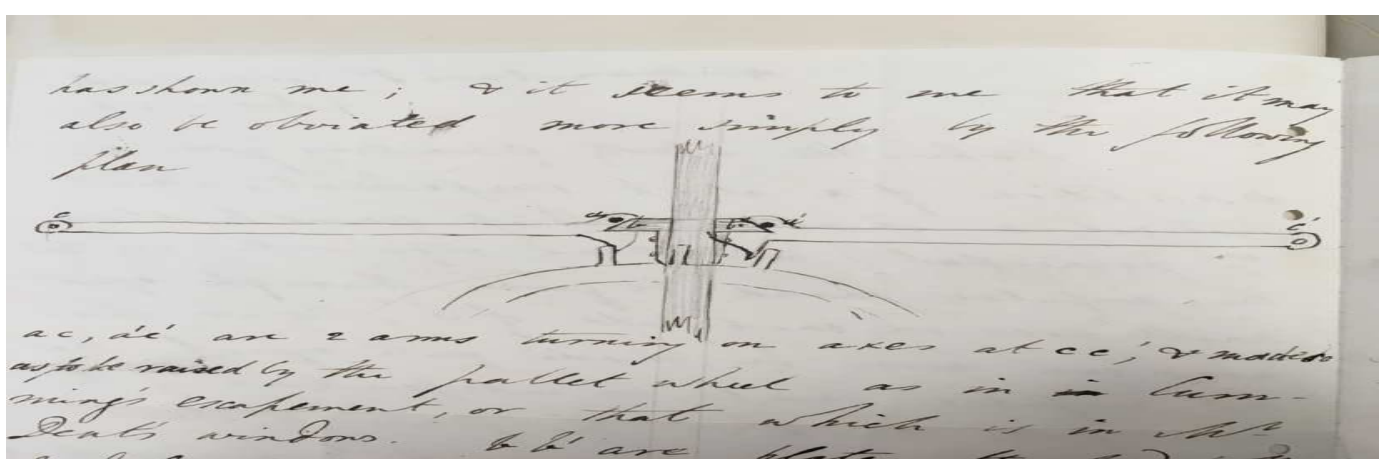

Figure: Denison's initial escapement proposal, which he sent to Airy in 1846 (RGO/6/607, E. B. Denison to Airy (14 Dec., 1846), pp. 171-2, 172)

Denison's horological skill, combined with some careful deference to Airy's published work and willingness to act on written suggestions, persuaded the Astronomer Royal to invite the gentleman mathematician officially onto the Westminster Clock project in November 1851. Denison flattered the astronomer, observing that on the subject of smoothrunning clock-wheel teeth, the 'most comprehensive view of the whole theory' was Airy's. ${ }^{33}$

30 RGO/6/607, E. B. Denison to Airy (14 Dec., 1846), pp. 171-2.

31 RGO/6/607, Airy to E. B. Denison (15 Dec., 1846), pp. 173-4.

32 RGO/6/607, E. B. Denison to Airy (23 Dec., 1846), p. 175. 
For the next two years, Airy and Denison collaborated with Dent in designing the timekeeper. By January 1852 the two gentlemen had drawn up plans for Dent to realize. ${ }^{34}$

This arrangement of Dent as builder, Denison designer, and Airy as supervisor, was in many respects an acknowledgement that the task of producing the nation's foremost timekeeper required a range of skills and experience. Yet it also revealed that while Airy trusted Dent's craftsmanship, he wanted a wrangler to be responsible for the horological design. Dent was a highly skilled 'mechanic', but a mechanic all the same, and Airy was loathe to hand responsibility for the project over to an artisan. So while both Denison and Airy emphasized Dent's practical ability, they were anxious to designate a clear line of authority between their theoretical mathematical knowledge and Dent's mechanical experience. Nevertheless, this often proved a hard ideal to realize.

On completing their initial design in late January 1852, Denison wrote to the First Commissioner of Works, Lord Seymour, stating that only Dent could be allowed to build the machine and that Airy shared this view. They did 'not think there is any other person who is actually able to make a clock so different in construction from those of all other makers except Mr Dent'. Anyone else would require so much 'instruction and constant personal superintendence from us as we could not give'. Furthermore, as Airy and Denison had in effect adapted Dent's own designs, albeit considerably, they felt it would be unfair 'in our teaching other persons how to copy the contrivances and construction which Mr Dent has introduced'. ${ }^{35}$ Trust was central to this collaboration between theory and skill. Denison explained to Airy that their drawings contained 'sufficient information for Dent to be able to judge what the clock will be ... no doubt he will trust us not to impose any unreasonable requisitions on him as to details ... I know we may trust him to be anxious to outdo not only the rest of the world but himself' ${ }^{36}$

This was particularly evident for the clock's escapement, the precise form of which would be the result of Denison and Airy's calculations, and 'experiments now making by $\mathrm{Mr}$ Dent' in his workshop. ${ }^{37}$ Early on, the escapement strained relations between the collaborators. In the designs of January 1852 Denison opted for a remontoire motion, but disliked the liability of 'the remontoire spring to be affected by damp'. Still, such a device reduced friction in comparison to all gravity escapements which relied on wheels and pinions. ${ }^{38}$ Airy too preferred a spring remontoire to a gravity, but did 'not like the remontoire

33 Denison, Edmund Beckett, A Rudimentary Treatise on Clocks and Watches, and the Bells; with a full account of the Westminster Clock and Bells, (London, 1860), p. 261.

34 RGO/6/608, ‘Clock for New Palace Westminster, 1851-1856', E. B. Denison to Airy (17 Nov., 1851), p. 108.

35 RGO/6/608, E. B. Denison to Lord Seymour (29 Jan., 1852), p. 52.

36 RGO/6/608, E. B. Denison to Airy (28 Jan., 1852), p. 118.

37 RGO/6/608, E. B. Denison, 'Specifications with two drawings of the Great Westminster Clock', (29 Jan., 1852), p. 120.

38 RGO/6/608, E. B. Denison to Airy (31 Jan., 1852), p. 127. 
in Dent's shop' because of the axis of its scape wheel. ${ }^{39}$ Denison and Airy disagreed over the accuracy of gravity escapements in general, with Denison believing such devices, consisting of two arms which were alternately raised and dropped a fixed distance to provide a constant impulse to the pendulum, to produce little friction and only minor arc variations. ${ }^{40}$ This was a tricky subject, however, because Dent had been making such remontoires for years, while no one else in England had ever built more than two. Denison put the problem succinctly: 'until some new construction turns up which is manifestly better, it is impossible for me to require him to abandon or alter this'. ${ }^{41}$ Dent wrote to Airy to reassure him that he could protect the remontoire spring from damp by oxidization and enclosing the mechanism within a glass cover, while to prevent the coils of the spring from rubbing together, he had a new invention. He proudly reported that the clock in his shop on the Strand, which employed a remontoire, had been going for twelve months without more than a two second deviation from Greenwich time. $^{42}$ Airy agreed that they had little choice but to trust Dent's 'experience on this point' and rely on his well-trained methods, despite theoretical objections. ${ }^{43}$ The designing of the clock's escapement would involve a careful management of mathematical and mechanical skill, as would the building of the entire machine.

\section{Model Solutions}

In the early 1850 s, horological drawings moved between the Observatory at Greenwich and Dent's workshops on the Strand and Cockspur Street in Westminster. Designs in Denison's hand travelled around London, with Airy and Dent providing annotations along the way. These were important spaces of inscription, but they were not the only forms of interaction between gentleman mathematician and artisan. ${ }^{44}$ Models represented the crucial transition between theoretical paperwork and working clock parts, and these too were mobile objects. Models provided Dent with a medium through which to challenge and revise mathematical drawings; while plans were the work of Denison and Airy, physical models allowed Dent to express what was, and what was not, mechanically pragmatic. They embodied artisanal authority.

From his earliest involvement on the project, Dent dealt in models. Models had been central to Airy's earlier work with the clockmaker. In 1836 Airy wanted the escapement he had devised 'on mere theoretical considerations' for his 1826 Cambridge Philosophical

39 RGO/6/608, Airy to E. B. Denison (2 Feb., 1852), pp. 129-30, 130.

40 Charles McKay, Big Ben: the great clock and the bells at the Palace of Westminster, (Oxford, 2010), p. 135.

41 RGO/6/608, E. B. Denison to Airy (5 Feb., 1852), pp.136-7, 137.

42 RGO/6/608, E. J. Dent to Airy (13 Mar., 1852), p. 272.

43 RGO/6/608, Airy to E. B. Denison (13 Mar., 1852), p. 271.

44 For spatial themes in the history of science, see Crosbie Smith and Jon Agar (eds.), Making Space for Science: territorial themes in the shaping of knowledge, (Basingstoke, 1998); David N. Livingstone and Charles W. J. Withers (eds.), Geographies of Nineteenth-Century Science, (Chicago, 2011). 
Society paper employed for a mantel clock. In January he sent plans to Dent, who produced a model of the escapement by July, which Airy trialed in his office at Greenwich later that year, suggesting modifications the following year. ${ }^{45}$ When Dent secured the commission to build two regulators for Pulkovo Observatory, near St Petersburg, Airy proposed a new device he had devised, his 'remontoire dead beat escapement'. Dent liked the design and so built a model, complete by June 1842, which subsequently went on display at the Royal Astronomical Society. ${ }^{46}$

When later competing for the contract to build the Westminster Clock, Dent had to provide details of the arrangement of clock wheels and dimensions of the frame. In January 1847 he forwarded 'a card-board model of the block frame' to the Office of Woods and Forests for Airy to check. This came complete with wooden wheels, to show how they could easily be removed when the clock required maintenance. Not only was this quarter-sized model easy to transport across London but, as it was made of wood and card, it was possible for the Astronomer Royal to mark on any proposed alterations. ${ }^{47}$ Dent and Airy subsequently met up and considered how best to arrange the wheels, employing the cardboard model in these discussions. ${ }^{48}$ This was a valuable object of social and mechanical negotiation.

When Denison joined Airy and Dent's partnership, this transaction of drawings and models continued, with Denison working at his Westminster home, various gentleman's clubs, or around Parliament itself, Airy at Greenwich, and Dent on the Strand. Denison's letters to Airy provide rare insights into this process of converting thoughts into drawings. On $24^{\text {th }}$ March 1852, while considering how to suspend the clock's pendulum, Denison reported how it had 'occurred to me ... in the street' to put the clock along, rather than across, the shaft of the tower. The next day he wrote that he planned to 'make some drawings of it this evening, and I have got a plan in my head'. The following afternoon he reported that he had 'got the drawings done last night, and I also had an opportunity of talking to Dent about the pendulum suspension'. ${ }^{49}$ Not only is it clear from this that Dent had input into the formation of plans, but that working in close proximity was an important aspect of the design process, and converting ideas into drawings, and drawings into models.

45 J. A. Bennett, J. A., 'George Biddell Airy and Horology', Annals of Science, Vol. 37, Issue 3 (1980), pp. 269$85,271$.

46 J. A. Bennett, J. A., 'George Biddell Airy and Horology', Annals of Science, Vol. 37, Issue 3 (1980), pp. 26985, 272; Mercer, The Life and Letters of Edward John Dent, p. 125.

47 RGO/6/607, E. J. Dent to T. W. Philipps (4 Jan., 1847), p. 144; on Bruno Latour's comments on models, and inscription, see Nick Hopwood and Soraya De Chadarevian, 'Dimensions of modelling', in Soraya De Chadarevian and Nick Hopwood (eds.), Models: the third dimension of science, (Stanford University Press: Stanford, 2004), pp. 1-15, 2.

48 RGO/6/607, G. B. Airy, 'Memoranda of conversation with M. Dent on Saturday 1847 Jan. 23' (23 Jan., 1847), pp. 146-7, 147.

49 RGO/6/608, E. B. Denison to Airy (24 Mar., 1852), p. 179; RGO/6/608, E. B. Denison to Airy (25 Mar., 1852), p. 184; RGO/6/608, E. B. Denison to Airy (26 Mar., 1852), p. 185. 
By April 1852 Dent had completed 'a large working model' of Denison's three-legged escapement, which he sent to Denison's home for inspection. On receiving it, Denison observed its performance, reporting that it 'certainly goes with wonderfully little friction; but I should like to see it in regular going in a clock before I give a decided opinion upon it'. ${ }^{50}$ After Airy gave his approval of the escapement and Denison observed the model working over the course of a month, a 'large scale' device was commissioned at the end of May. In the meantime, Dent had taken the model to Paris for French horologists to inspect. ${ }^{51}$ Dent subsequently built the full scale three-legged escapement for trials, which by late August was 'going to perfection'. Denison recommended Airy travel to Dent's factory to see it going, observing that the device had greatly reduced the force lost to friction encountered in a common escapement; comparing the three-legged with a traditional dead-beat escapement, Denison found the amount of weight required to swing the same pendulum was reduced by almost a quarter. ${ }^{52}$ Airy could 'quite conceive the great diminution of friction' of the new escapement, but before agreeing to its adoption would have first to see it in action, and also have the smaller model sent down to Greenwich and set going in his office for an extended period of time. ${ }^{53}$ While Airy and Denison were generally happy with this escapement, feeling it 'theoretically' worked efficiently, after seeing 'the brass working model', Denison's mind was changed, and he developed a new arrangement to diminish the force of the remontoire arms. $^{54}$

Airy kept the small brass model going in his office at Greenwich from late August until mid-December, when he returned it to Dent's workshop. However, by late 1852 Denison had changed the escapement's design again, having seen the full scale version in action. He wrote to Airy reporting that the 'box containing the model has just arrived', but it was of no use to either Dent or himself, 'as there is the thing itself to look at instead'. So while the model provided a way of observing an escapement in motion in several different places beyond the workshop, it quickly became redundant. Denison had designed his new double three-legged gravity escapement in response to observations of the full-sized threelegged gravity escapement, built to his original plan. In trials, it became apparent that this earlier design went too fast. After watching this initial escapement, Denison recalled that the new design "came into my head ... and much as I was pleased with the other three legged one, it was still liable to the objection that it requires attention to the oil, on account of the dead friction'. ${ }^{55}$

50 RGO/6/608, E. B. Denison to Airy (1 Apr., 1852), p. 192.

$51 \mathrm{RGO} / 6 / 608$, Airy to E. B. Denison (6 Apr., 1852), p. 195; RGO/6/608, E. B. Denison to Airy (27 May, 1852), pp. 199-200, 200.

52 RGO/6/608, E. B. Denison to Airy (25 Aug., 1852), pp. 208-9, 208.

53 RGO/6/608, Airy to E. B. Denison (26 Aug., 1852), p. 210.

54 RGO/6/608, E. B. Denison to Airy (10 Nov., 1852), pp. 213-4.

55 RGO/6/608, E. B. Denison to Airy (27 Nov., 1852), pp. 218-9. 


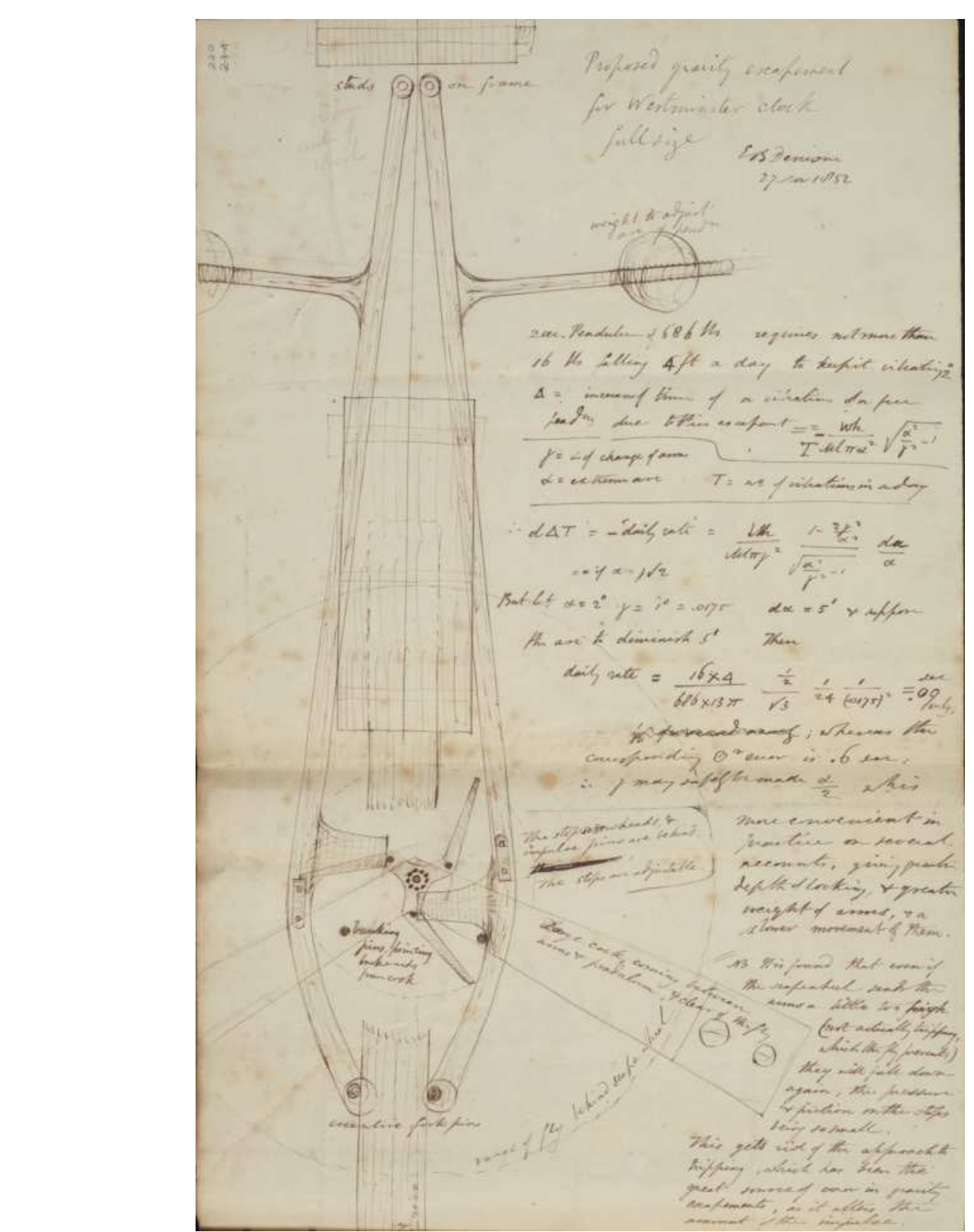

Figure : Denison's three-legged gravity escapement from November 1853 (RGO/6/608, E. B. Denison to Airy (27 Nov., 1852), p.220)

Airy disliked the new device, having a low opinion of gravity escapements as they were at risk to the slightest accident caused by the 'touch of a workman's finger', and he insisted on sticking to the three-legged, the model of which was satisfactory. ${ }^{56}$ Yet the fact that Airy's opinion was informed only by observing the model undermined his position. Denison asserted that 'when you have seen it in real life' Airy would follow Denison and the horological jury of the Great Exhibition, 'who all preferred the old 3 legs at first, but after they had seen this in action, and tried for themselves to make it go wrong or alter the arc of the pendulum, all came to the opinion that though the other is the prettiest to look at, this is the best for actual work'. ${ }^{57}$ While Dent employed models to exert his own authority over the

56 RGO/6/608, Airy to E. B. Denison (18 Dec., 1852), p. 221; on workmen and mechanisms see, Bulstrode, 'Riotous assemblage and the materials of regulation', pp. 304-5.

57 RGO/6/608, E. B. Denison to Airy (18 Dec., 1852), pp. 222-3, 222. 
escapement's design, Denison's management of these experimental devices was different, using them carefully to manage the Astronomer Royal's supervision of the project.

Dent agreed with Denison, who maintained that the improvement could not be appreciated from the smaller model. 'What you could hardly see from the model', he continued, was the advantage over other gravity escapements the new design possessed. ${ }^{58}$ Denison recalled how six years earlier, the Astronomer Royal had told him that if a clock escapement with no continuous friction during the action on the pendulum could be combined with the principles of a remontoire, 'the great problem of clockmaking will be mastered' ${ }^{59}$ The new escapement achieved this, having no continuous friction, with it being taken up by the arms during the action on the pendulum.

By late January 1853, there was a model of this newer device complete in Dent's workshop and, according to this, the larger three-legged escapement was reconstructed. ${ }^{60}$ In early March, Denison sent calculations of the daily rate of the new escapement, which suggested it would vary by less than $1 / 12^{\text {th }}$ of a second per day. ${ }^{61}$ Airy requested that the small working model of the revised device be sent down to Greenwich before he confirm Denison's calculations, and found that the rate remained very consistent, even if the arc of vibration was disturbed, and as a result was happy to adopt the new escapement. ${ }^{62}$

In discussions over the form of the clock, including its frame, wheel arrangements, and escapement, models provided ways of analyzing and examining designs, but they also embodied authority. While a model allowed Dent to exert his own clockbuilding experience, Denison used Airy's reliance on models in the absence of regular trips to Dent's workshop as a way of undermining the Astronomer Royal's resistance to alterations to the escapement's design. As well as 'mediators between theories and phenomena', models were spaces of negotiations between contrasting forms of authority. ${ }^{63}$ In reference to the design of ships' hulls, Simon Schaffer explained that 'When model-makers designed, tried, and showed their well-behaved models, they could claim the right to govern and represent the macroscopic systems these models represented' ${ }^{64}$ For Dent, this was certainly apparent; the practice of

58 Ibid., p. 222.

59 Ibid., p. 223.

60 RGO/6/608, E. B. Denison to Airy (31 Jan., 1853), pp. 224-5, 224.

61 RGO/6/608, E. B. Denison to Airy (2 Mar., 1853), pp. 233-5.

62 RGO/6/608, Airy to E. B. Denison (6 Jun., 1853), pp. 236-7.

63 Nick Hopwood and Soraya De Chadarevian, 'Dimensions of modelling', in Soraya De Chadarevian and Nick Hopwood (eds.), Models: the third dimension of science, (Stanford University Press: Stanford, 2004), pp. $1-15,1$.

64 Simon Schaffer, 'Fish and ships: models in the age of reason', in Soraya De Chadarevian and Nick Hopwood (eds.), Models: the third dimension of science, (Stanford University Press: Stanford, 2004), pp. 71105, 72; on mathematics and models, see Herbert Mehrtens, 'Mathematical models', in Soraya De Chadarevian and Nick Hopwood (eds.), Models: the third dimension of science, (Stanford University Press: Stanford, 2004), 
modelling allowed him to demonstrate the limits of mechanical arrangements and phenomena such as arc deviation. With Airy and Denison both keen to preserve lines of authority between themselves and the clockbuilder, models provided Dent with materials for asserting his own knowledge claims.

\section{Devious Devices}

Models were not the only objects through which Dent, Denison, and Airy negotiated the form of the Westminster Clock. Like models, the various devices comprising the clock not only materially embodied mechanical questions, but social values. One of the most important concerns for the collaborators was how to regulate the clock and correct deviations. For Airy, this was the crucial horological question. He assumed it 'a fundamental point for a clock which is to have great authority with the public that there must be means of making small adjustments in its indication'. ${ }^{65}$ The traditional method was to have a system of manually adding or removing weights to the pendulum to either accelerate or retard its beating. This was something Dent and Denison favoured, but Airy preferred the construction of a device that would automatically apply or remove weight. Distrusting the 'workman's fingers', Airy would only consent to a manual system of pendulum regulation if 'the attendant can soon acquire the practical skill of putting on or taking off the weights'. ${ }^{66}$ While he trusted Dent and Denison's experience in the matter, he feared clumsy workmen would shake the pendulum rod. Arguably, Dent attributed greater skill and authority to workmen than Airy did. In 1836, Dent informed Airy that opinions on chronometers were best given from 'a person having a thorough knowledge of the construction of the machine, and should be undertaken by the Principal, as Workmen are supposed to be best acquainted with some particular part, which he is in the habit of producing' ${ }^{67}$ For Dent, making was knowing.

Airy's solution to his concerns over human error was to have a rack-and-pinion device at the top of the pendulum, controlling a sliding weight near the pendulum's end; this would be easily adjustable by an untrained assistant. Airy first proposed this apparatus for making small alterations to a clock's beating in November 1846. Employing a sliding mechanism, to add or reduce weight to the pendulum, this offered a precise way for untrained workmen to accelerate or slow its beating. ${ }^{68}$

pp. 276-306; on model experiments and instrumentation, see W. D. Hackmann, 'Scientific Instruments: models of brass and aids to discovery', in David Gooding, Trevor Pinch, and Simon Schaffer (eds.), The Uses of Experiment: studies in the natural sciences, (Cambridge, 1989), pp. pp. 31-65, 45-58.

65 RGO/6/608, Airy to E. B. Denison (1 Mar., 1853), pp. 231-2, 231.

66 RGO/6/608, Airy to E. B. Denison (16 Mar., 1852), p. 170.

67 Mercer, The Life and Letters of Edward John Dent, p. 43.

68 RGO/6/607, G. B. Airy, 'Apparatus for producing small changes in the indication of a large clock', (16 Nov., 1846), pp. 269-76. 

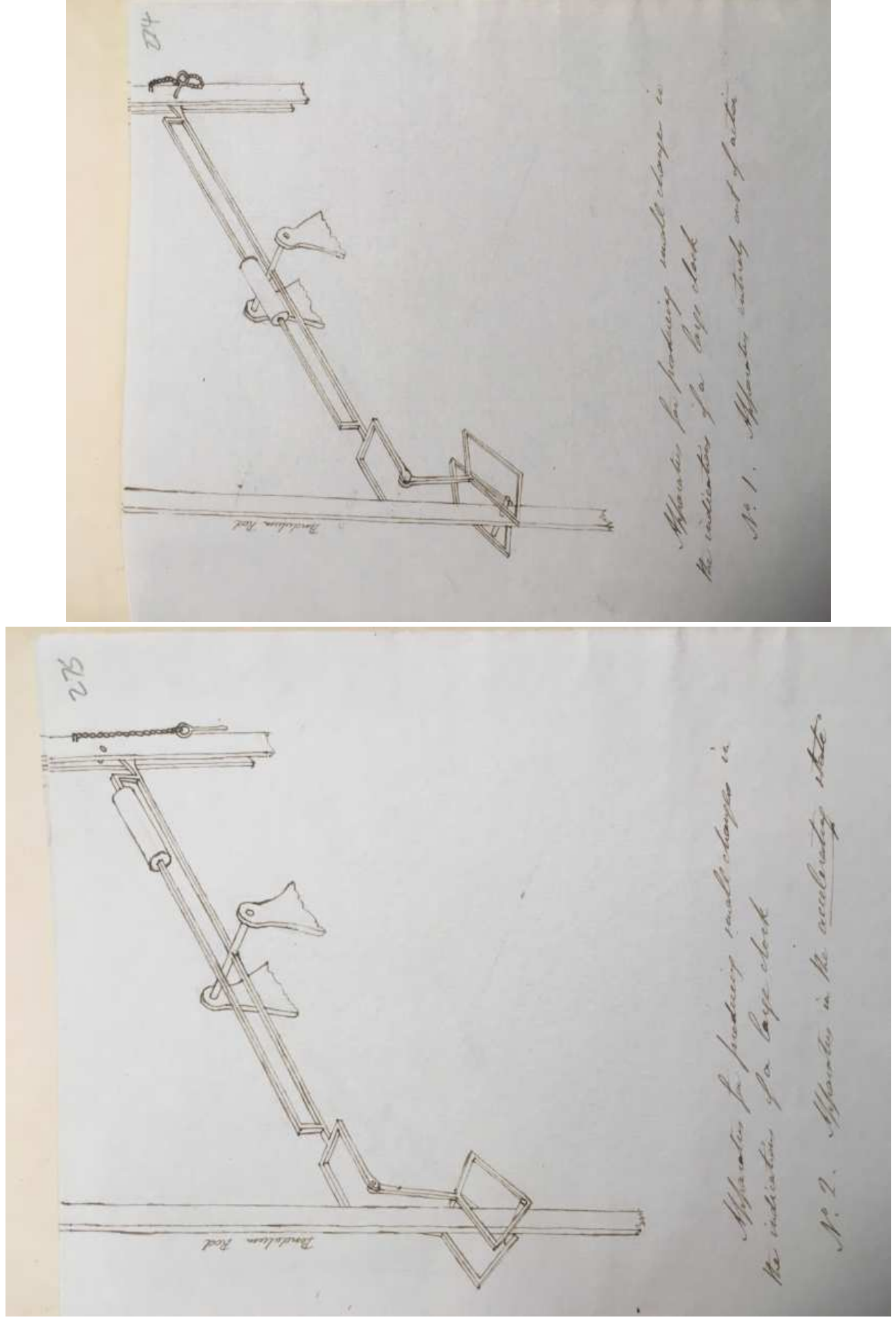


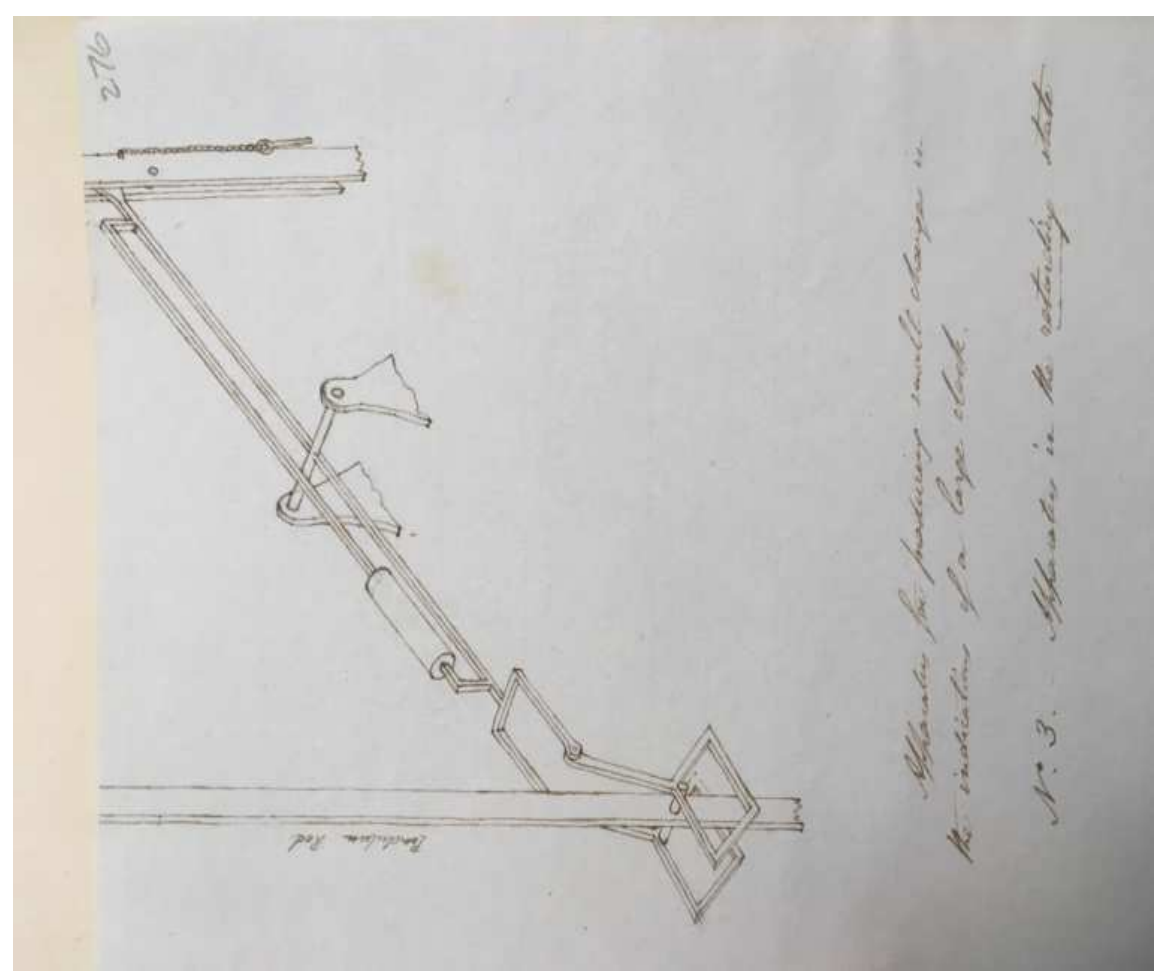

Figure: Airy's sliding rack-and-pinion mechanism for applying or removing weight to the pendulum (RGO/6/607, G. B. Airy, 'Apparatus for producing small changes in the indication of a large clock', (16 Nov., 1846), pp. 269-76, 274-6)

Denison was amused by Airy's 'pendulum-retarding apparatus', but thought manual correction would be safer; he warned that if Airy's device was too slow in correcting the pendulum, workmen would just grab hold of the rod and correct themselves. ${ }^{69}$ Airy had his pendulum-retarding apparatus constructed and invited Denison to Greenwich to see it work, confident that witnessing the device would convince the gentleman horologist. Denison did not initially accept Airy's invitation to view his device directly and remained skeptical, believing the 'new apparatus would not retard the pendulum as quickly' as more trusted forms of correction. Nevertheless, he was 'open to conversion on the whole of this pendulum adjustment question' and promised that if on seeing the device he was convinced of its merits, he would order the new contrivance be introduced. However, Denison warned that until he saw 'it really acting ... I shall leave Dent at liberty'. ${ }^{70}$ Here, delegating to Dent's practical experience provided Denison with a strategy for rejecting the Astronomer Royal's novel inventions. Denison was unimpressed with the proposal, believing it overly complex, and reiterating that the most reliable way of correcting a two to three second daily deviation was to have a collar attached, on which small weights could be manually placed. ${ }^{71}$ It is unclear if Denison ever travelled to Greenwich to witness Airy's apparatus, but he certainly used the distance between the Observatory in East London and Dent's workshop in Westminster as a convenient means to avoid engaging with proposals he thought impractical. Clearly the

69 RGO/6/608, E. B. Denison to Airy (3 Feb., 1852), pp. 131-3, 131.

70 RGO/6/608, Airy to E. B. Denison (4 Feb., 1852), p. 134; RGO/6/608, E. B. Denison to Airy (5 Feb., 1852), pp. 136-7, 136.

71 RGO/6/608, E. B. Denison to Airy (7 Feb., 1852), pp. 145-6, 145. 
power balance between Airy and Denison took on a spatial character, which though potentially managed by exchanging models across London, could leave the Astronomer Royal rather isolated at Greenwich.

In response to Denison's disobliging behaviour, Airy encouraged him to work by the 'two following expressions', namely, 'until I see ... I shall leave Dent at liberty', and 'until some new construction ... it is impossible for me to require him'. ${ }^{72}$ While the two could only act together by 'mental concessions', there was one point on which Airy demanded 'a somewhat greater ... influence', and that was for the apparatus regulating the pendulum. ${ }^{73}$ Although Denison was careful not to give 'the impression that ... [he] meant to assume any independent authority', he maintained that 'as Dent is not bound to introduce anything which we do not concur in requiring, he is if so facto "left at liberty". ${ }^{74}$ Denison was unwilling to 'introduce any new invention into this clock without being satisfied of its value', because he felt 'more responsible' for the clock's general construction. As a result, he was anxious 'that nothing should fail, or be open to the charge of being a mere fanciful novelty' ${ }^{75}$

What is apparent from Airy and Denison's differences over the extent to which they would trust Dent in designing the clock's mechanisms is that Airy was more anxious to discipline the artisan mechanic. It seems likely that this reflected Airy's insecurities over his own social position. Unlike Denison, who could grant Dent considerable autonomy in the project, without risking any hierarchical boundaries between gentleman and artisan, the grammar school-educated and financially limited Astronomer Royal was far more aware of the lack of class demarcation between himself and Dent. As much as tensions between skilled craftsmen and gentlemen mathematicians, the disagreements over clock apparatus revealed Airy's personal class consciousness.

After several exchanges between the two university-educated mathematicians, the question of pendulum regulation descended into a heated argument. While Airy reassured Denison that each of his opinions would 'have at least as much weight with me as my own', this witticism was followed by a blunt assertion of authority. ${ }^{76}$ Airy lamented that regarding 'our common business, it appears to require a line of conduct seriously different from what I had anticipated'. He determined that 'when we differ upon any point, that point is to be abandoned to the judgement of Mr. Dent', who would evaluate their opinions, 'or take a different opinion of his own'. ${ }^{77}$ At the same time, while the Astronomer Royal would be 'guided' by Dent's judgement, he reiterated that the artisan was 'subordinate to us, and I cannot consent to give to a subordinate a power greatly exceeding that of our official

72 RGO/6/608, Airy to E. B. Denison (6 Feb., 1852), pp. 140-2, 141.

73 Ibid., p. 141.

74 RGO/6/608, E. B. Denison to Airy (7 Feb., 1852), pp. 143-4, 143.

75 Ibid., p. 143.

76 RGO/6/608, Airy to E. B. Denison (7 Feb., 1852), p. 146.

77 RGO/6/608, Airy to E. B. Denison (9 Feb., 1852), pp. 149-50, 149. 
authority. ... Any differences of opinion between us must be settled either by us or by a superior authority'. ${ }^{78}$ Airy insisted he was happy to make concessions, but observed that if there were any points he could not resolve with Denison then he would have to refer them to Lord Seymour.

In response, Denison felt the discussion was 'assuming a very unpractical turn', as the main source of confrontation was over Airy's retarding apparatus. Denison reminded Airy that he had promised to show him a trial of the device, but that this had not yet happened; indeed, 'the first symptom of disposition to carry things by some other method than argument or experiment was not exhibited on this side of the water'. ${ }^{79}$ He warned Airy not to appeal to any 'umpire between us', but to rely on mathematical negotiations and Dent's experience. If Airy pursued such an official line of authority he would, instead of 'driving Dent to acquiesce in your views', in fact 'leave him at liberty to do exactly as he pleased'. ${ }^{80}$ Optimistically he recommended 'throwing this auxiliary ... train of correspondence out of gear ... we shall do more good by discussing the flexibility of remontoire-springs than of resolutions'. In finding resolutions, Dent's mechanical knowledge would be of greater value 'than the superior authority of any First Commissioner' ${ }^{81}$

A month later, Denison confirmed that he and Dent had agreed against Airy's device, preferring to make adjustments by putting on or taking off weights to 'a broadish collar' fixed half way down the pendulum rod. Trials in Dent's workshop found this allowed the pendulum to be retarded a few seconds within just a few minutes, and likewise accelerated by adding weights. Using an $8 \mathrm{ft}$ pendulum, Denison 'found that either I or his men could do it without any difficulty'. ${ }^{82}$ In this way, he rejected Airy's mechanical contrivance for removing human error from the clock's regulation; with the Astronomer Royal somewhat isolated down at Greenwich, workshop trials and Dent's trusted techniques were enough to ensure his device was not employed for the Westminster Clock.

Airy and Denison's disagreement over how to regulate the pendulum was primarily a question of trusting instruments or workmen, but it also engendered very different understandings of what the Westminster Clock should be. While Airy envisioned an immensely accurate machine, delicate in construction, Denison wanted the clock to be built on an unprecedented scale; accurate of course, but also greater in size to previous timekeepers. After reviewing Denison's initial plans in January 1852, he was concerned at the proposed pendulum of $5 \mathrm{cwt}$, fearing such a weight would cause 'the whole tower to swing' ${ }^{83}$ Denison admitted this choice was 'chiefly a matter of fancy to have it the heaviest

78 Ibid., p. 149.

79 RGO/6/608, E. B. Denison to Airy (10 Feb., 1852), pp. 151-2, 151.

80 Ibid., p. 152.

81 Ibid., p. 152.

82 RGO/6/608, E. B. Denison to Airy (15 Mar., 1852), pp. 168-9, 168.

83 RGO/6/608, Airy to E. B. Denison (30 Jan., 1852), pp. 125-6, 125. 
in the world'; the clocks of the Post Office and Royal Exchange had pendulums of about 4cwt. ${ }^{84}$ Airy, however, did not share this sense of pendulum hubris. He explained that he did not 'sympathize with your desire for a heavy pendulum. It is, I think, a moment of the ancient barbarism, whose people knew no other way' of constructing a clock than with a crude action and large hands. 'Instead of setting up the heaviest pendulum in the world', Airy believed it would 'be a far greater triumph to set up the lightest pendulum in the world' ${ }^{85}$ Airy's intention here was to make the pendulum's regulation simpler; less weight would make it easier to adopt his pendulum-retarding device. What Airy envisaged was a smaller, lighter device, 'making it go as well as a chronometer', which would be more difficult with a heavy driving weight. ${ }^{86}$ Denison refused to give way, conceding that while it 'would be a greater triumph to make the clock go (equally well) with a light pendulum than with a heavy one', he was convinced 'that we shall achieve the most important triumph of making it go with the least possible variation by having as heavy a pendulum as we can safely manage' ${ }^{87}$ An increased pendulum weight, he explained, would increase the clock's driving force without the addition of much friction to the escapement.

\section{Gentlemanly Behaviour}

This three-way collaboration came to an end in March 1853 with the death of Dent, whose health had been in rapid decline since early 1852. Nevertheless, the tensions between Airy and Denison continued, with the task of building the clock handed on to Dent's stepson, Frederick Rippon Dent, who had previously worked closely with Denison. ${ }^{88}$ In November 1853 Airy withdrew from the project altogether, but this was not because of differences of opinion between him and Denison over mechanics, but over gentlemanly behaviour. Questions of instrumentation and horological accuracy severely strained the relationship between the two Cambridge mathematicians, but it was over their cooperation with architect Charles Barry and authority over Dent in this matter that they reached the ultimate impasse.

Since Dent's appointment to the project ahead of Vulliamy, Barry had remained supportive of his initial choice of clock-builder. As a result, Denison remained 'incurably suspicious of Barry as an inveterate jobber' and refused to trust him with drawings or specifications. ${ }^{89}$ In March 1852 Dent informed Airy that Barry had contacted him, requiring a private meeting. When they met, Barry had demanded drawings of the clock, but Dent refused, considering the clock plans to be property of Denison and Airy. Furthermore, Dent believed it odd that Barry wanted such detailed drawings which were irrelevant for preparing

84 RGO/6/608, E. B. Denison to Airy (31 Jan., 1852), p. 127.

85 RGO/6/608, Airy to E. B. Denison (2 Feb., 1852), pp. 129-30, 129.

86 Ibid., p. 129.

87 RGO/6/608, E. B. Denison to Airy (10 Feb., 1852), pp. 151-2, 151.

88 Gillin, The Victorian Palace of Science, pp. 245-7.

89 RGO/6/608, E. B. Denison to Airy (10 Jun., 1852), pp. 201-2, 201. 
the tower for installation. ${ }^{90}$ Both Dent and Denison feared Barry wanted the drawings to either discredit them, or pass them on to Vulliamy, but Airy wrote to Barry apologizing for Dent's overzealousness, stating that he had acted with 'responsibility much more decidedly than was necessary'. ${ }^{91}$ He provided Barry with details of the clock and together they visited the clock tower and discussed the size of the clock and space required for the pendulum. Airy ordered Dent to 'let him see all' and hand plans over to Barry. ${ }^{92}$

Denison took a much tougher line, arguing that if he wanted any information, Barry would have to make an official request. After Dent's 'strange interview' with Barry, Denison warned Dent that 'we are sure to come in for some more of the abuse of Vulliamy and his party (of which Barry is one), and his present proceedings are evidently taken with that view ... we had better keep him at arm's length'. ${ }^{93}$ According to Denison, Barry's attempts to get details of the clock betrayed his ulterior motive of helping Vulliamy restore his position as clockbuilder. Denison refused to trust the architect. However, for Airy this this was an immensely disreputable approach to business. In May 1852, Denison's fears were confirmed when a printed paper was circulated in the House of Commons discrediting Dent's clock and claiming that Vulliamy had been cheated out of the government contract. Denison was sure Barry was behind the publication, but Airy refused to get involved. ${ }^{94}$ In June Airy informed Denison that he had not seen the paper, and that 'I shall not notice it in any way'. He advised Denison ignore the paper. ${ }^{95}$ Denison, however, was furious, penning a response against the paper attributed to 'the jobbers and anticompetition men'. ${ }^{96}$ Airy disliked Denison's eagerness to get into a public argument with Barry over the clock. It was not the act of a gentleman to publically disagree over work commissioned and paid for by the government.

It was this divergence which eventually compelled Airy to abandon the project and leave the clock in Denison's hands. Throughout 1853 Barry and Denison's negotiations grew increasingly fraught. Airy disapproved of Denison's secrecy towards the architect, but in November received a letter from Denison explaining how he had 'heard so much of Sir C Barry's unsatisfactory behaviour, that I am quite determined to keep in his right position ... he has been from the beginning trying to trip us up and get this job into his own hands; and I have only one way of dealing with people of that kind' ${ }^{97}$ In response, Airy demanded

90 RGO/6/608, E. J. Dent to Airy (19 Mar., 1852), pp. 273-4, 273.

91 RGO/6/608, Airy to Charles Barry (20 Mar., 1852), p. 58.

92 RGO/6/608, Airy to E. J. Dent (20 Mar., 1852), p. 275.

93 RGO/6/608, E. B. Denison to Airy (10 Mar., 1852), pp. 175-6.

94 RGO/6/608, E. B. Denison to Airy (10 Jun., 1852), pp. 201-2, 201.

95 RGO/6/608, Airy to E. B. Denison (11 Jun., 1852), p. 205.

96 RGO/6/608, E. B. Denison to Airy (12 Jun., 1852), pp. 206-7, 207.

97 RGO/6/608, E. B. Denison to Airy (1 Nov., 1853), pp. 254-5, 254. 
Denison retract his letter and act with decorum. For Airy, Denison's attitude was 'not satisfactory' and he disagreed with his assertion 'to keep him ... in his right position': such conduct Airy felt 'would not be becoming to me'. ${ }^{98}$ Denison refused Airy's request completely and refused to share any clock drawings with Barry unless the architect clearly explain to what purpose he needed them. Four days later, Airy withdrew from the project. ${ }^{99}$ Airy wrote to William Molesworth informing him that while he was impressed with Denison's 'mechanical ingenuity and horological knowledge', he could not 'act in concert' with him any longer. Airy resigned from the project explaining how Denison's behaviour revealed 'that our ideas of the mode of conducting public business are very different' ${ }^{100}$ Molesworth implored Airy to continue his duty of examining and certifying the clock on completing, to which Airy agreed, specifying that he only declined 'any business which might imply continued conference with Mr Denison'. ${ }^{101}$

This compromise angered Denison, who believed this confused questions of authority over the project. He wanted Airy to withdraw altogether so that he alone could give instruction to the clockbuilders. Drawings required signatures, but if Airy had withdrawn, Denison wanted it made clear that his own 'authority is sufficient'. ${ }^{102}$ Airy's ambiguous position was irksome for Denison. In April 1854 Denison once again demanded clarification, reporting how the Board of Words refused to trust him as the sole designer for the clock; he told Airy that 'they do not understand your position to be altered' ${ }^{103}$ The Board refused to work with Denison alone. Rather than return to the project, or abandon his position as the clock's certificatory, Airy repeated insistence that 'it is quite out of our power efficiently to act in concert ... [but] It will be necessary for me, at the proper time, to give my certificate'. ${ }^{104}$

Rumors of Denison and Airy's disagreement soon became public. In the Mechanics' Magazine in 1857, Denison denied allegations that he had pushed the Astronomer Royal off the project, while the clockmaker E. T. Loseby used the same journal to undermine Denison's reputation. ${ }^{105}$ Loseby reported that Airy had not previously known Denison, until he had opportunistically put himself forward and then worked to seize complete control of the

98 RGO/6/608, Airy to E. B. Denison (3 Nov., 1853), pp. 256-7, 256.

99 RGO/6/608, E. B. Denison to Airy (3 Nov., 1853), pp. 258-9, 258; RGO/6/608, Airy to E. B. Denison (7 Nov., 1853), p. 260.

100 RGO/6/608, Airy to William Molesworth (7 Nov., 1853), pp. 76-7.

101 RGO/6/608, Airy to William Molesworth (14 Jul., 1855), p. 92.

102 RGO/6/608, E. B. Denison to Airy (21 Nov., 1853), pp. 261-2.

103 RGO/6/608, E. B. Denison to Airy (1 Apr., 1854), p. 264.

104 RGO/6/608, Airy to E. B. Denison (4 Apr., 1854), p. 266.

105 E. B. Denison, 'The Westminster Clock and bell', Mechanics' Magazine, (London, England), 7 Feb., 1857, pp. 132-3. 
project. He revealed that when Airy had resigned his supervision, Manners had suggested Robert Stephenson be appointed as the clock's new referee, but that Denison had defiantly rejected this, claiming there was 'no power now existing in anybody to subject Mr. Dent to the control of any other persons, besides those to whom he is subjected by his contract'. ${ }^{106}$ After the subsequent general election, no further referees were suggested, but the House of Commons had found Denison so rude and uncooperative that they had unsuccessfully tried to sack him and draw up a new contract with Frederick Dent. Several years later, Loseby published a tract accusing Denison of subsequently ignoring all of Airy's recommendations. Despite Airy demanding wheels of gun-metal, with teeth cut to epicycloidal form, Denison had ordered iron wheels with cast-iron teeth. The clock was, as a result, 'destitute of the promised workmanship'. Along with being underpowered, Loseby also felt Airy would be disappointed with the clock's accuracy. The Astronomer Royal had wanted a dead beat escapement of astronomical accuracy, with a minute hand constantly moving to show the passing seconds. Denison had instead produced a gravity escapement with a minute hand only moving each sixty seconds. Furthermore, the clock's hourly striking was unlikely to be accurate with the escapement highly likely to trip because of the heavy pendulum. ${ }^{107}$ Loseby also felt Dent's trials to be insufficient; workshop performances were 'like trying a locomotive for its power without attaching any train to it'. The problem, as he saw it, was that Denison had assumed too much authority over the project, being in effect both 'designer and referee'. ${ }^{108}$

Airy did certify the clock after reporting on the completed mechanism in 1860. In hindsight he reflected that 'the whole thing ought to have been at first intrusted [sic.] to a Clock-maker under the superintendence only of Government Officers' and regretted giving Denison so much authority and 'proper power' over the clock's construction. ${ }^{109}$ However, he was satisfied Denison had produced a reliable time-piece. Airy raised several minor concerns, including complaints from MPs over the loudness of the clock's main bell, the excessive weight of the clock-face hands, and the liability of the escapement to trip. ${ }^{110}$

When Airy eventually certified the finished clock, he did indeed have reservations as to accuracy. While he could not 'look into every detail of a machine so complicated', the 'general workmanship' was excellent. Yet since he had left the project, he regretted to see the escapement had been changed, with the remontoire removed and replaced with a double three-legged escapement, which had a risk of tripping. ${ }^{111}$ Recognizing the big challenge in

106 E. T. Loseby, 'The Westminster Clock and bell', Mechanics' Magazine, (London, England), 14 Mar., 1857, pp. 252-3.

107 E. T. Loseby, On the Westminster Clock, (W. P. Cox: Leicester, c. 1859), pp. 2-3.

108 Ibid., pp. 3 and 5.

109 RGO/6/609, Airy to W. Cowper (30 Jun., 1860), pp. 103-4, 104.

110 RGO/6/609, Airy to E. B. Denison (9 Apr., 1860), pp. 131-2.

111 RGO/6/609, Airy to W. Cowper (21 Apr., 1860), pp. 30-7, 30 and 32. 
the project had concerned authority, Airy lamented that he thought 'that the whole thing ought to have been at first intrusted [sic.] to a clock-maker under the superintendence only of Government officers, the course which I originally contemplated, till M. Denison determined to draw every plan himself'. ${ }^{12}$ In April 1860, Airy sought an explanation for this change, observing that while all escapements were 'theoretically liable' to trip, this was especially possible with the current mechanism. He still preferred the remontoire which had no 'risk of tripping'. ${ }^{113}$ Denison maintained that the double three legged reduced friction and pressure, while the remontoire was removed as he was 'frightened at the momentum of the hands jumping 7 inches when I came to try it'. ${ }^{114}$

\section{Conclusion}

In the popular and technical press, the Westminster Clock was celebrated as a great scientific work. The Times, Mechanics' Magazine, and The Builder all included detailed reports of the machine, while The Morning Herald boasted of the clock's accuracy, claiming it would not lose two beats in every four million vibrations. ${ }^{115}$ The paper reported that in trials lasting two months, the timekeeper lost just 2.8 seconds and claimed that there was 'something exceedingly appropriate in the desire that the great clock at Westminster should be the best that science can furnish, for the first authentic record which we have of clocks in this country is in connection with one that stood in the old clock tower opposite Westminster Hall, in the time of the early Plantagenets'. Despite this romanticized uniting of antiquity and authority, the paper also noted that few 'subjects in modern times have given rise to more angry feelings, or excited more jealousies'. ${ }^{116}$ Such publications informed a broad readership both of the clock's technical precision and the difficulties involved in building it.

The completed Westminster Clock was, and in many ways still is, a very public projection of accurate, regulating time. It is a machine which mechanically disciplines the daily business of the Houses of Parliament, and embodies broader notions of regulating the nation. At least, this is what it was intended to be. Actually constructing it, however, was a social, as much as a technical, challenge. The complexity of the machine created ambiguities over the lines of authority between elite gentleman mathematician and skilled clockmaker. Practical artisanal practices and experiences had to be combined with mathematical expertise and horological theory, in order to physically realize the clock and transform ideas and drawings into wheels and escapements. This translation relied on mundane practices, tools,

112 RGO/6/609, Airy to W. Cowper (30 Jun., 1860), pp. 103-4, 104.

113 RGO/6/609, Airy to E. B. Denison to Airy (9 Apr., 1860), pp. 131-2, 131.

114 RGO/6/609, E. B. Denison to Airy (10 Apr., 1860), pp. 133-4, 133.

115 (Anon.), 'The tower and clock at Westminster', The Times, (London, England), 18 Nov., 1857; p. 6; Issue 22841; (Anon.), 'The clock-tower, Westminster New Palace', The Builder, (London, England), 31 Jan., 1857, p. 62; (Anon.), 'The bell and clock for the Houses of Parliament', Mechanics' Magazine, (London, England), 30 Dec., 1855, pp. 584-5; RGO/6/608, cutting from The Morning Herald (10 Sep., 1855), p. 317.

116 RGO/6/608, cutting from The Morning Herald (10 Sep., 1855), p. 317. 
and exchanges, but it also involved careful management. As Airy and Denison grew anxious about their authority over the work, models and mechanical trails provided material solutions to navigate the hierarchy between artisan and gentleman of science.

Yet models and mechanisms were not just materials through which universityeducated mathematicians and skilled craftsmen negotiated social hierarchies: they also engendered tensions between gentlemen of contrasting class backgrounds. When Airy left the Westminster Clock project, this was clearly not just about Denison's conduct towards Barry, but the last of a series of disagreements between the two gentlemen mathematicians in which social position was central. As a solid member of the British aristocracy, Denison had no doubts over his own eminent rank. Airy, on the other hand, was constantly aware of his humble origins and lack of material wealth. Their varying degrees of privilege shaped their dealings with each other, with Dent, with workmen, and towards Barry. It was of greater urgency to Airy to promote gentlemanly behaviour towards the architect, exert authority over Dent, and to be wary of granting workmen too much authority, because his own credentials were far shakier than Denison's. The materials of building the Westminster Clock were, therefore, crucial spaces of exchange between mechanics and gentlemen of science, as well as between socially elite and anxious middle class mathematicians. Realizing mathematical designs as physical devices was both a social and a mechanical process. 